\title{
CUSTOMER ORIENTATION AS A BASIC PRINCIPLE IN THE CONTEMPORARY ACTIVITY OF THE BANK
} https://doi.org/10.47743/jopafl-2021-21-05

\author{
Larisa MISTREAN \\ Academy of Economic Stadies of Moldova (University), Faculty of Finance \\ Chisinau, Republic of Moldova \\ mistrean_larisa@ase.md
}

\begin{abstract}
An open and sincere orientation towards solving problems and satisfying customer needs is the key used by marketing to open the door to success for any business. There is only one way to create and sustain superior long-term performance by a financial institution: exceptional customer care backed by constant innovation. In fact, banks have adopted the concept of marketing as a utility - the ability to create and retain profitable consumers - and see the customer as the main driving force of their business. Creating customers requires the bank to monitor the business environment in order to react promptly to changes in the needs of existing and potential consumers of financial-banking services, so that they become loyal customers of the institution. In contemporary economic conditions, consumers can choose what, when, how and how often to buy a product. The better the bank's offer synchronizes with the requirements, preferences and desires of consumers, the more loyal they become to the financial institution, willing to use more financial products and services, generating profit for the bank. The strengthening of customer relations becomes even more current in the conditions of the Covid-19 pandemic crisis, arising from the need to maintain a very close contact with customers to ensure good information about changes taking place at the network level, about the measures taken by the bank, about the possibilities of remote banking, etc. This situation forced the banking management to look at things differently, to change certain visions and approaches, because it caused the approach and acceleration of the processes that were foreseen for a more distant future. The main objective of this study is to provide a practical perspective of the customer orientation of the bank activity in order to retain the consumer of financial services and, thus, ensure the viability and stability of its activity.

Keywords: Customer orientation, customization, financial-banking services, preferences and desires of consumers, bank's client, customers' needs, customers' behavior, marketing.
\end{abstract}

This Article was presented as a paper at the $13^{\text {th }}$ edition of the Annual International Conference Globalization and Higher Education in Economics and Business Administration (GEBA 2021), which was held at the Alexandru Ioan Cuza University, Faculty of Economics and Business Administration in Iasi, Romania from the $21^{\text {st }}$ to $23^{\text {rd }}$ of October 2021.

\section{Introduction}

The objective of the banking activity is to maximize the profit by increasing the sales revenues and consolidating the position on the market, the realization of which is possible by ensuring the satisfaction of the consumers of financial-banking services. In order to achieve the expected performances, the banks must satisfy the demands of the customers through its products and services. The bank's customer orientation should be seen as a customer relationship management tool designed to generate long-term sustainable profits by ensuring management of target customers and available capital. At 
the same time, the bank's customer orientation in modern banking becomes one of the most significant competitive advantages, which determines the institution's ability to generate additional profit through deep understanding and efficient satisfaction of customer needs. Against the background of accelerated global development, the banking system is experiencing an ongoing struggle for existing and potential customers. In order to ensure a stable activity in the conditions of intensifying the competition on this market, the banks develop customer orientation strategies, which in fact represent a continuous interaction between the bank and the client, a relationship started and constantly maintained by them. Customer orientation means ensuring a quality product or service, at all times, for customers who request it. In the current economic conditions, banks actively participate in the development of financial services, being focused on the client and his needs. In relation to the client's needs, banks create the necessary tools to model complete financial services packages and modules for a good relationship between the financial institution and its client, meant to support the modeling of the country's economic process.

Given that the offer of products and services has multiple common characteristics and aims to meet the same needs, each bank is required to stand out through its customer orientation strategy. Thus, the bank management aims to implement a customer orientation policy based rather on ensuring the relational balance, the communication between the bank employee and the customer becoming an advantageous exchange of information. The most important element of this strategy is to communicate in as many ways as possible with potential and current customers in order to attract and retain them. Strengthening the relationship between the bank and customers requires the existence of a permanent demand for improvement. If meeting customer needs is a priority for the bank, then the bankcustomer relationship will ensure loyalty and, consequently, the customer will be loyal to the bank. Customer gratitude is the best and cheapest marketing tool. A larger number of customers gives the bank a more advantageous position than its competitors and, respectively, a larger market segment, which will ensure a long-term profit. Decoding the consumer's needs requires extensive research on the criteria for purchasing decisions, criteria that express the consumer's point of view on his own needs. The orientation towards the client, towards his real needs, is obligatory in an efficient banking management approach.

\section{Literature review}

An institution is successful insofar as it manages to develop very good relationships with customers (immediate beneficiaries of its products and services) and if it has the capacity and ability to provide products and services appropriate to the needs and at that level of quality that brings customer satisfaction. Customer orientation assumes that the institution that knows what the customer wants and expects must ensure that the product or service developed is consistent with those expectations (Ettlie, 1994). In essence, customer orientation means respecting the wishes and needs of the customer, anticipating them and then acting accordingly (Barends, 2019). During the evolution, the following possible interpretations of the term customer orientation were manifested, which emphasize different aspects and working principles. 
Table 1. Customer orientation according to situational interpretation

\begin{tabular}{|c|c|c|c|}
\hline $\begin{array}{c}\text { Informational } \\
\text { orientation }\end{array}$ & $\begin{array}{l}\text { Kohli/Jaworski } \\
\text { 1990, Kohli și al. } \\
\text { 1993, Johnson } \\
1998 \\
\end{array}$ & $\begin{array}{l}\text { Acquisition, analysis and use } \\
\text { of customer information. }\end{array}$ & $\begin{array}{l}\text { Systematic and periodic } \\
\text { studies on customer } \\
\text { satisfaction and loyalty. }\end{array}$ \\
\hline $\begin{array}{l}\text { Philosophical } \\
\text { and cultural } \\
\text { orientation }\end{array}$ & $\begin{array}{c}\text { Kobi/Wütrich } \\
1986\end{array}$ & $\begin{array}{l}\text { Employee behavior in relation } \\
\text { to customers, treatment } \\
\text { applied to customers. }\end{array}$ & $\begin{array}{l}\text { Workshops on culture, } \\
\text { seminars, analysis and } \\
\text { processing of models of } \\
\text { situations and behaviors. }\end{array}$ \\
\hline $\begin{array}{c}\text { Orientation } \\
\text { towards results } \\
\text { and interaction }\end{array}$ & $\begin{array}{c}\text { Homburg 1998, } \\
\text { Homburg/Werner } \\
1998\end{array}$ & $\begin{array}{l}\text { Quality of products and } \\
\text { services, interactive customer- } \\
\text { oriented behavior by fully } \\
\text { meeting customer } \\
\text { expectations. }\end{array}$ & $\begin{array}{l}\text { High quality of products and } \\
\text { services, active complaints } \\
\text { management, fast and } \\
\text { uncomplicated reaction to the } \\
\text { special requests of customers, } \\
\text { strong motivation of } \\
\text { employees. }\end{array}$ \\
\hline $\begin{array}{l}\text { Orientation from } \\
\text { the perspective } \\
\text { of the company } \\
\text { and the client }\end{array}$ & $\begin{array}{l}\text { Meyer/Dornach } \\
\text { 1998, } \\
\text { Homburg/Werner } \\
\text { 1998, Droege } \\
\text { \&Comp. } 1998\end{array}$ & $\begin{array}{l}\text { Quality of advice, } \\
\text { responsiveness to customer } \\
\text { proposals, responsiveness and } \\
\text { sincerity in informing clients. }\end{array}$ & $\begin{array}{l}\text { Activities regarding customer } \\
\text { structuring, measuring } \\
\text { customer satisfaction and } \\
\text { customer loyalty. }\end{array}$ \\
\hline
\end{tabular}

Source: Bruhn, M., 2004, pp. 17-24

Zaltman (2003) states that a firm that focuses on customers and listens carefully to their opinion has a future. This gives the management team the information they need to assess how big the challenge is, especially in terms of their latent needs, and ensures improved teamwork, the creation of a business model and a successful marketing plan.

Although today's customers are more different from each other, more discerning and more demanding than before, the problem of marketers has remained the same: knowing customers, developing solutions to their needs, establishing with them an appropriate link that leads to customer satisfaction and profit collection from the activity carried out (Fisk, 2008).

The relationship with the client is achieved through a continuous interaction between the client and the institution, a relationship that must be developed and cultivated. In order for a potential customer to become a customer attached to this institution, the bidder-customer relationship goes through the following stages: potential customer, probable customer, first purchase customer, occasional customer, loyal customer. From a low level of knowledge about a customer, a high level of knowledge can be reached through this relationship, and the level of customer attachment is measured by: the duration of the relationship with the customer and the number of transactions (Kreutzer et al., 1991). The customer-oriented institution promotes a different approach, called intuitive-reactive marketing: listening to customers, using different distribution channels, innovative market offerings, etc. (Kolter, 2004). Judicious customer knowledge provides an opportunity for the institution to make more efficient use of distribution channels, market opportunities, factors of production, and assets. Customer orientation is directly related to the goods and services of the institution, as well as the interaction between the bidder and the client. Thus, this concept is described by a dynamic relationship between the client and the institutions. 
The primary goal of customer orientation is to meet customer needs, expectations, ensure maximum utility of the product and service to the customer, and not to gain an advantage over competitors in the market (Bruhn, 2001). An enterprise is customer-oriented when its activity meets the following characteristic features: high quality of products and services, active management of complaints and notifications, rapid and uncomplicated response to special customer requests, strong employee motivation (Bruhn, 2001). An interactive customer-oriented behavior is distinguished by the total satisfaction of customer expectations, by an appropriate relationship with employees of the institution, including cases of complaints or special wishes.

Of course, the process of attaching the customer to the supplier is particularly complex and includes several stages: a) analyzing customers according to potential, b) segmenting customers according to their value, c) researching customer satisfaction, d) wording recommendations for strategy and action (Eskert, 1994). Each stage involves the knowledge and use of a specific tool and the undertaking of multiple actions. In this way, the customer's attachment to the bidder is the result of a process of implementing customer orientation. In order to maintain the relationship with customers, barriers can be established, which make it difficult for the customer to migrate (Fornell et al., 1992) and which can be achieved through a number of tools: the provision of certain clauses in contracts, the provision of facilities through price, communication of financial, social or psychological risks, formation of customer habits, etc.

The keystone in building lasting relationships with customers is to ensure a higher degree of value and satisfaction for the customer. Satisfied customers are more likely to become loyal customers, and loyal customers are more likely to give the institution a larger share of the purchases they make (Kotler, 2004). The principle of customer orientation implies that the bank does not focus on its product as such, but on the real needs of customers. At the same time, banks do not abandon the forced imposition of services and focus on maximum customer satisfaction. This requires a clear statement of the bank's objectives, the formation of ways and means to achieve them and the development of specific measures for the implementation of plans to segment existing and potential customers (Лосева \& Козлов, 2015).

\section{Customer orientation in banking}

Contemporary banking is a customer-oriented one, adopted in order to increase the level of consumer satisfaction, as well as the loyalty of those of particular importance to them. To this end, banks continuously identify and collect customer data and information in order to shape their offer in line with their priority objectives. Customer orientation is a guarantee of the success and maintenance of the financial institution on the market, which leads both to the loyalty of attracted customers and to the acquisition of solid competitive advantages. Creating a "portfolio" of customers is an increasingly difficult task today, because being assailed by a wide variety of products and services, brands, prices and suppliers, attracting customers means first and foremost, deciphering the mechanism of thought and action of customers, in making the decision to opt for a particular brand or product. Banks currently adopt and demonstrate a clear customer orientation, justified by the following: 
- the demands of consumers of financial-banking services are constantly increasing and banks need to adapt their products and services to meet them;

- competition in the banking market is fierce and competitors are introducing improvements to catch up and outperform innovative financial institutions;

- customers are quickly getting used to the banks' offer and have higher and higher expectations.

Thus, in order to maintain their market positions and strengthen it, banks focus their efforts on understanding and meeting the needs and expectations of current and potential customers. In this respect, increased attention is paid to the performance and conformity of the product and service, the assigned costs, the delivery method, the degree of safety, the impact on the current activity and the future evolution.

The bank as a financial intermediary is considered to be customer-oriented if:

- the offer includes high quality products and services. Quality is the best policy for ensuring customer loyalty, the most effective way to defend against competition from other banks and non-banking financial institutions, as well as the only way to develop and collect expected profits. In fact, there is a direct relationship between the quality of products and services, the level of customer satisfaction and the profitability of the bank. The financial institution needs to know how consumers perceive the quality of its products and services and what quality they expect to receive and, respectively, should try to offer more in terms of quality than its direct competitors. In contemporary conditions, what is defined by banks as a top banking product or service will soon be perceived by the customer as a minimum quality standard, creating important challenges for the customer loyalty and retention process. The major danger in this context becomes the ease of the process of changing the banking partner for any customer - currently, globally, about $40 \%$ of customers are not sure that they will not change their partner bank over a period of 6 months;

- applies active complaint management and pays special attention, a quick response to special consumer demands. Although banks seek to retain customers by ensuring their high satisfaction with the quality of products and services, there are many cases where customers are dissatisfied. This can be capitalized by implementing complaints management as an important element of a customer-oriented activity, given that specialized studies show that two out of five customers leave their current banking partner after the first negative experience. The development of complaints management by banks aims to promote the development of a favorable relationship with customers, increase customer satisfaction and loyalty. Thus, it is intended that, following the development of specific complaints management processes, through the way the bank reacts to the dissatisfaction expressed by customers, customer satisfaction will be restored. Customers' reactions to their dissatisfaction with the bank's products or services may vary: they may migrate, complain, complain or communicate negatively with third parties. By applying complaints management, the financial institution meets these reactions, aiming to obtain for customers the satisfaction of resolving complaints as a result of the process of processing information by the complainant, which compares the subjective expectations related to handling and resolving the complaint by the bank with the actual conduct of the process of receiving, processing and resolving the complaint;

- applies a strong motivation of employees. In order to provide excellent customer service, the bank's human capital should be sufficiently motivated. Every employee is able to positively or negatively influence the client's perceptions and preferences. Based on a 
mentality, a "marketing culture", the bank's staff, especially those in the front office can at some point turn an "apparent" problem into an opportunity or competitive advantage.

Customer orientation is essential to achieving customer satisfaction. A perspective on customer expectations and satisfaction allows financial institutions to improve customer orientation. Monitoring customer satisfaction produces important information that makes it possible to supervise their business and improve bank-customer relations. Once the bank knows what it likes and does not like about certain categories of customers, it can implement improvements oriented towards certain objectives, which is, in fact, the customer-oriented itself.

Customer financial satisfaction results from:

- saving money (for example: a lower interest rate, set for loans from the bank, lower fees or cancellation for certain services);

- monetary gain (for example: a favorable interest rate for the resources kept in the bank account);

- the possibility to get extra comfort (for example: access to account resources at any time from any corner of the world).

Adding value-satisfaction to the products and services offered by the bank can be achieved by personalizing them. Thus, the bank's customer-oriented approach is a system of management measures of the financial institution, which offers its customers support and satisfaction of their requirements for a bank-customer reality, which ensures the solution of the problem of attracting, retaining customers and developing a customer base. Customer orientation measures include:

- at corporate level: organizational structure, business processes, technologies, standards, IT infrastructure, Public Relations (PR), etc.;

- at individual level (level of a specific employee), including staff selection and training.

The basic pillars of a customer-oriented activity, which will ensure the efficient management of customer expectations, both corporate and retail, determining the improvement of the quality of banking products and services are:

- knowledge of the client and his needs: his preferences according to risk aversion, his behavior regarding investments and savings, customization of products and services according to the client's life cycle (be it a legal entity or an individual). Banks must respond to the financial needs of customers with a personalized offer, ensuring the gaining of customer trust through mutually beneficial long-term relationships by building "win-win" relationships, both quantitatively and qualitatively;

- harmonization of the relationship between the banking product and the promotion and distribution channel. Optimizing distribution and promotion channels involves moving from the current situation of channel development to the next step: developing products and services to maximize channel efficiency;

- increasing trust in the bank by ensuring a high degree of transparency, financial education, taking into account the interest of each client at any time and situation. Bank customers not only want to get money or capitalize on their savings, but they want a more personalized relationship with the financial institution, a relationship that gives them confidence and a sense of control over this relationship. Differentiation is obtained at the level of trust and satisfaction;

- strengthening the customer-bank relationship through care, quality and frequency of interaction. Attention must be focused on customer retention by understanding the factors 
that determine their satisfaction rather than the repetitiveness of the act of consumption. Customer satisfaction throughout the life cycle of the established relationship is a premise for their retention and subsequent loyalty;

- development of unitary policies and strategies regarding the characteristics (eg price, structure) of the offer of products and services at the level of all promotion and marketing channels, strategies whose main point is customers, with their real needs, understood through economic, behavioral filters, emotional and moral. The strong migration in the digital space has determined banks to develop products and services adapted to this environment, as well as to engage in building communities with their customers, where the main condition is that any communication approach is transparent, in a language accessible to consumers.

\section{Orientation of the bank towards the client in the conditions of the COVID-19 pandemic}

The period of the COVID-19 health crisis gave birth to the "new client", more vulnerable, insecure and less in control than ever, more financially constrained, looking for interactions without direct contact and more prudent in decisions. In order to succeed - and perhaps even survive - in this new reality, banks have had to become more connected, more digital and more customer-oriented than ever. The situation we are in is unprecedented, affecting every aspect of our lives and creating a "new normal" of daily life, the rules of economic activity and personal life. The way in which financial-banking services are consumed has evolved a lot during this period, characterized by a great impact, both from the point of view of the activity, and of the security and stability on the business environment. The COVID-19 pandemic has accelerated the digitalisation of the banking sector, as customer expectations continue to change, causing structural and supply and demand changes (Mistrean, 2021).

The pandemic has led to an incredible transformation, as banks have moved much of their operations and customer interactions into the digital space and have been forced to provide access to customers using alternative, remote, online channels. In order to survive the crisis and continue their activity, banks have been forced to adapt quickly to new circumstances, conditions in which digitalisation presents a multitude of challenges in the complexity of day-to-day operations. In this way, banks have developed their remote service systems, offering consumers more convenience and safety. They provide consumers with access to banking services and products, from home, from work or from anywhere the customer feels comfortable and safe 24/7, from any geographical point. Banks have taken various measures to stimulate remote customer service, by introducing facilities for online transactions, necessary to retain customers, in terms of limiting visits to bank counters. In order to prevent the spread of COVID-19, consumers have been encouraged to use cashless payments, such as: payment cards, internet-payments applications, mobile payments, credit transfer (payment order), which allow payments to be made from any computer or mobile device.

New online banking facilities have been introduced, such as cash by code, cash withdrawal service without the presence of the card, online deposits at a better rate than the bank's counters, the application of preferential rates for the execution of remote payment orders, home delivery of cards, creation of online current accounts and free 
transfers between current, card and own deposit accounts, launching various products in support of SMEs and other categories of customers. In addition to the increased use of technology to sell products and services, various applications, emails and website messages are used to interact with consumers in order to maintain connectivity with customers. There are customers who, even if they have digital capacity and purchase digital products and services, they are not always able to satisfy their very specific, complex and urgent needs, requiring peer-to-peer services.

For people who prefer to go to the counter, the banks have provided a special selfservice place, equipped with ATMs and Self-Service Terminals, which offers cash out, cash in and payment operations. At the same time, they have the support of the banking staff - the meter greeter - who guides them to carry out the first online operations. Aware that customer revenues have been severely affected by the restrictive measures imposed in the context of the pandemic, banks in the Republic of Moldova as well as banks around the world have taken various actions to ensure continuity of collaboration with customers.

In this regard, the postponement of rates on bank loans has eased the financial burden, albeit in the short term, for many debtors in difficulty - companies forced to close or reduce their business, entities affected by supply chain problems, unemployed or low-income individuals.

On March 17, 2020, the Executive Committee of the National Bank of Moldova (NBM) issued a decision allowing the licensed banks the flexible management of the payment obligations of individuals in difficulty of payment for loans contracted, in conditions of urgency, and by the decision of April 3, 2020 the NBM allowed banks to postpone or change the deadlines for payments and the amounts of payments due until June 30, 2020 to loans to legal entities. In this regard, banks have offered customers (both individuals and legal entities) individually several facilities, both for loans, advances, and leasing receivables, such as: payment of loan installments and payment interest for the first months of the pandemic was transferred for payment in subsequent months; no penalties and late payment interest were charged; the loan repayment schedule was modified without charging the clients the commission for modifying the contractual clauses, etc.

As the danger has not passed, uncertainty about the evolution of the pandemic is growing, budget imbalances are widening and funding conditions are tightening, facilitating access to finance remains an objective to be met, to ensure the necessary mechanisms for economic regeneration. In this regard, the licensed banks of the Republic of Moldova continue to grant loans under the normal regime, in accordance with their internal policies and regulations and in accordance with the legal norms and regulations of the NBM. The banking market in the Republic of Moldova is, unfortunately, characterized by excessive standardization of certain products, such as credit, in order to shorten the analysis time of the applicant (which unfortunately came to be considered a factor of competitiveness) to a period that, as a rule, it is insufficient to understand the client and the specifics of the business to be financed. Accurate identification of the risks associated with these operations should be only a key factor in parameterizing (structuring) those transactions and not an absolute obstacle or approval for them.

The COVID-19 pandemic caused disruptions in economic flows and the lockdown caused delays in corporate cash flow, declining consumption in some areas and contributed to behavioral changes and as a result led to a reinvention of the business model for banks. from the Republic of Moldova and beyond. As the main financiers of the economy, the role 
of banks has become crucial - to help save the economy and jobs. Thus, banks need to rethink the traditional way of assessing potential borrowers, focusing on the importance of choosing the present moment. The value of new loans granted in national currency in September 2021 reached the figure of 3270,49 million MDL (Moldovan lei), which is a volume about 2,3 times higher than the volume of loans in lei granted in May 2020 1448,03 million MDL, in the conditions in which banks decreased the interest rate charged for these loans from 8,4\% in May 2020 to 6,84\% in September 2021. A positive trend is also recorded in the volume of loans granted in foreign currency, increasing from 505,42 million in MDL in May 2020 to 1199,05 million MDL in August 2021 (when they reached the highest level), which is an increase of over $137 \%$, given that the interest rate fell from 4,43\% in May 2020 at 3,89\% in August 2021. (see fig. 1).

Fig. 1. Evolution of the value of new loans granted by licensed banks in the Republic of Moldova and the weighted average annual interest rate during the pandemic crisis.

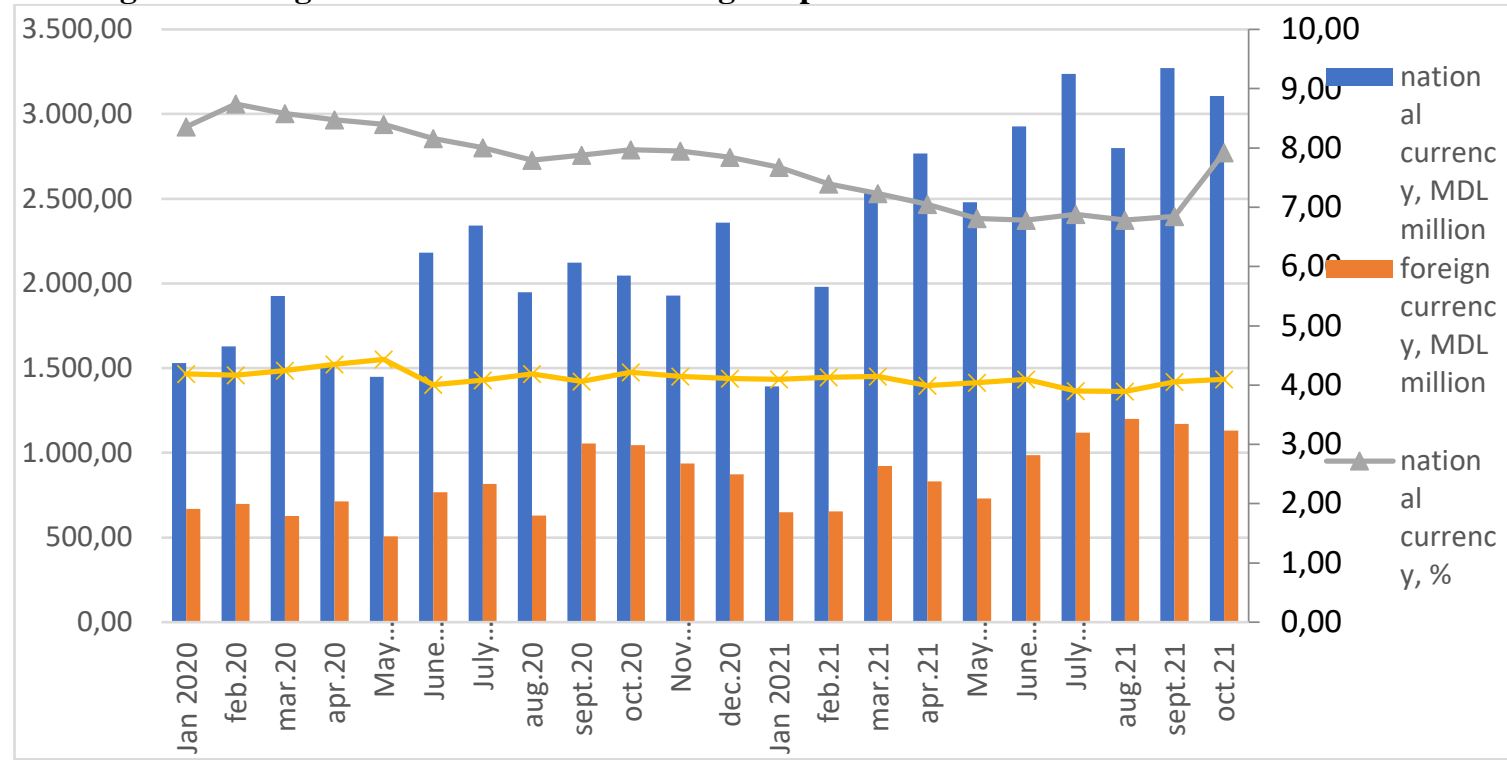

Source: National Bank of Moldova, (2021). Statistical databank. Retrieved from https://www.bnm.md/

In order to increase the volume of financial resources of banks, the National Bank of Moldova gradually reduced the established norm of required reserves from funds attracted in MDL and nonconvertible currencies (\%) from 41,5\% in February 2020 at 26\% starting with May of this year. The interest rate set for required reserves of funds drawn into MDL and non-convertible currencies held by banks at the NBM decreased from 2,5\% in February 2020 to 0,15\% starting in March 2021, and then increased to 1,98\% in September 2021 and 3,33\% in October this year. At the same time, the required reserve requirement for funds attracted in freely convertible currencies (FCC) has steadily increased from 20\% in February 2020 to 30\% since March 2021, in the conditions in which the interest rate established for the required reserves from the means attracted in convertible currencies maintained by banks at the NBM remained at the same level for the entire analyzed period $-0,01 \%$ (see fig. 2 ). 
Fig. 2. Modification of the norm of required reserves from the means attracted in MDL, nonconvertible currencies and freely convertible currencies, as well as of the remuneration rate of the reserves constituted during the pandemic crisis, (\%)

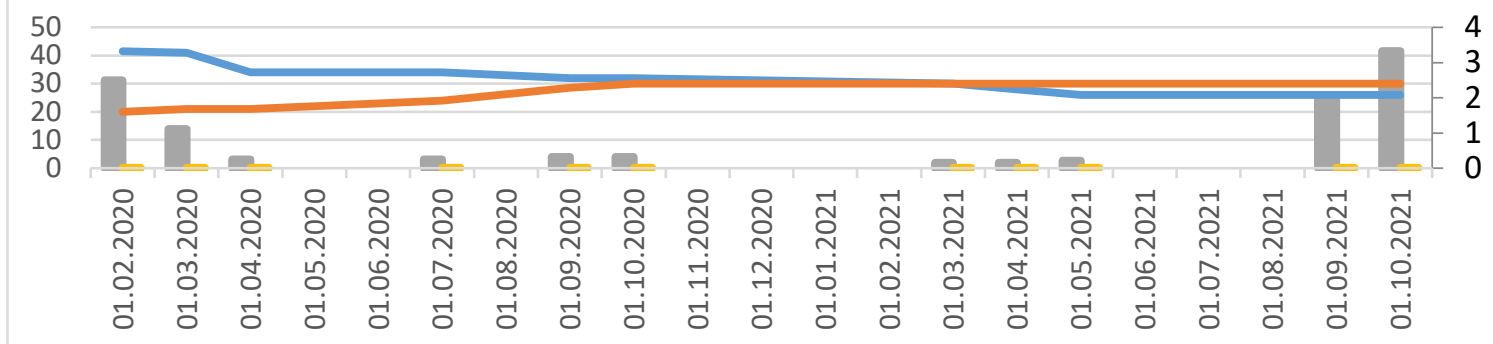

Remuneration rate on required reserves (MDL), \%

Remuneration rate on required reserves (FCC) (\%)

Required reserve ratio on liabilities in MDL and nonconvertible currencies, \%

Required reserve ratio set in FCC of the means attracted in FCC (\%)

Source: National Bank of Moldova, (2021). Statistical databank. Retrieved from https://www.bnm.md/

We must mention that even in the conditions of increasing the volume of bank loans, the need for banks in additional financial resources was insignificant and periodic, which proves that they have a high level of liquidity. Thus, the value of overnight loans granted by the NBM to licensed banks recorded the highest level in July 2021 - 40 million lei, in the other 6 months in which banks needed additional funds being much lower (see Fig. 3). The interest rate set by the NBM for overnight loans was 8,5\% in March 2020, being reduced in April 2021 to 5,15\%, after which it was set at 7.5\% in October 2021 (NBM explains this increase as an instrument of influence on the inflationary process in the country).

Fig. 3. Evolution of the value of overnight loans granted by the National Bank of Moldova to licensed banks and the interest rate set for them during the COVID-19 crisis, (\%)

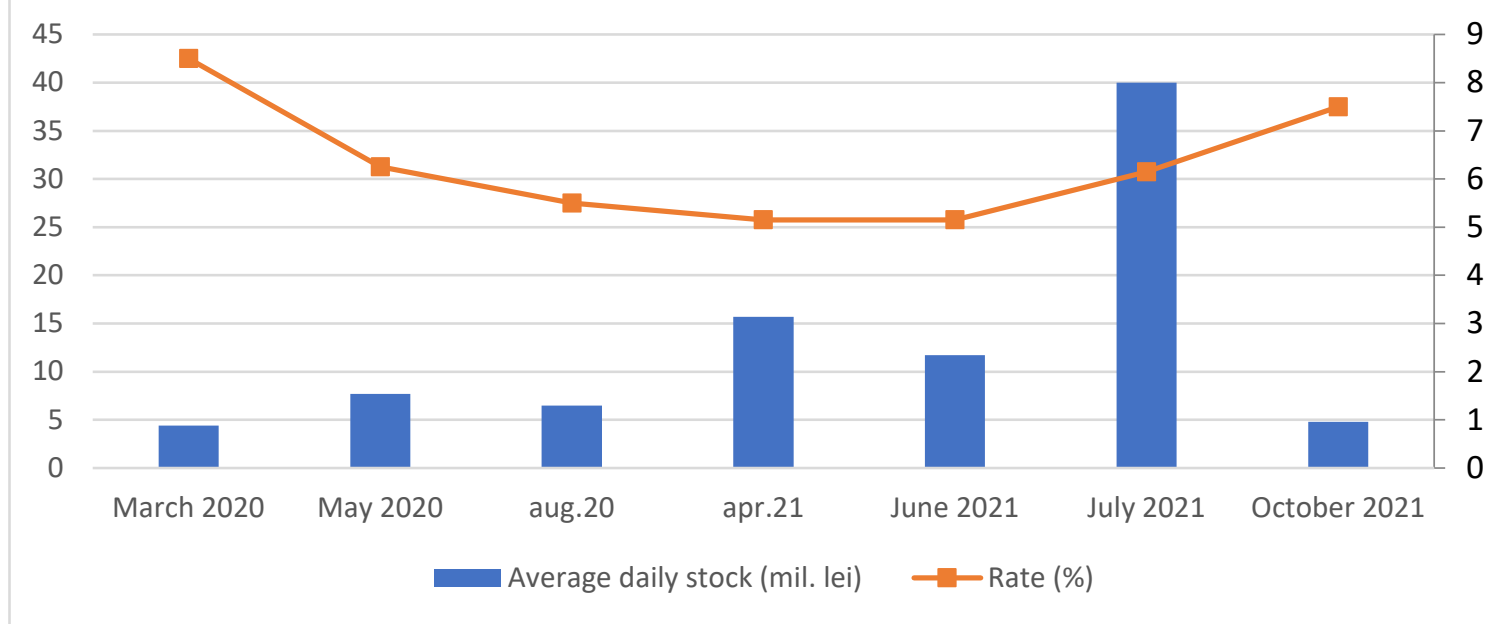

Source: National Bank of Moldova. (2021). Statistical databank. Retrieved from https://www.bnm.md/ 
As for universal banks, banking is the same all over the world, the differences are given by the different needs of consumers of financial-banking services. Banks need to know not only the basic needs (food, clothes, utilities, salaries) but also the more complex and sophisticated needs (investment plans, health plans, pension plan, etc.) and to meet them with appropriate supply. In the current context of the COVID-19 pandemic and the evolving needs and preferences, including digital ones, it is necessary for banks to be prepared to respond quickly and efficiently to unforeseen changes in behavior. At the same time, in addition to the implementation of a trend setters regarding the products and services and a high degree of technologicalization, the concern for the customer, manifested by the bank, matters the most. In order to survive, banks need to focus on readjusting and re-evaluating strategies at the customer approach level, as well as realigning internal processes and resources. Under these conditions, they must collect and analyze granular data and information through a deep and in-depth (re) evaluation of the customer base (including customer research, segmentation, customer journey, etc.) in order to later develop integrated experiences that will help them adapt and thrive in the new reality.

\section{Conclusions}

The bank's customer orientation can be seen as a customer relationship management tool designed to generate long-term sustainable profits, which determines its ability to generate additional profit through deep understanding and efficient satisfaction of customer needs. Increasing customer loyalty to the bank requires strengthening the customer orientation of all divisions of the financial institution that would ensure the identification of customer needs and satisfaction as efficiently as possible. The use of advanced technologies allows banks to use information from customer data to know their real needs and properly market their products and services to fully satisfy them, giving them full satisfaction and a desire to return to the bank for more products and services. Data is becoming the focus of digitization, and many banks are accelerating the adoption of digital technologies, such as data analysis, artificial intelligence, robotic advisors and blockchain, to gain competitive advantage in the face of the pandemic crisis and as well as in the post-COVID-19 period.

Under these conditions, digitization must be an effective mechanism for banks to maintain and improve the "customer-centric" philosophy by using digital channels, which will ensure the use of data and information obtained in the direction of proactive customization, based on relevance and opportunity, at customer, the offer of products and services. Thus, the collection and accumulation of customer data and information will provide a huge opportunity to increase the quality of products and services by creating CRM (Customer Relationship Management) analytical capabilities for the conversion of "unstructured data" to "structured data". Although, lately, the level of digitalization and automation of banking has increased considerably, bankers talk about the need for its further growth, to ensure an uninterrupted digital flow from the first contact with the customer (entry on the bank's website, research the bank's offer) until the sale of the product without human intervention (except for decision moments). However, banks continue to offer predefined, rigid products and services, the characteristics of which (term, amount, interest rate, etc.) do not change according to the needs of different subcategories of 
customers. The development of customized products and services will provide the customer with the desired comfort and satisfaction and the considerable increase of the banking business potential in a short time.

In order to achieve a customer-oriented activity, banks must directly address the following areas:

- redefining the bank's activity: placing the client and his needs at the center of all processes to ensure permanent solutions. Creating a customer-centric business model requires that banks understand and accept the uniqueness of each customer and create a real image of a partner in the bank-customer relationship by solving the needs of the customer and not the seller of financial products and services. At the declarative level, most banks support this strategy, in reality they are extremely far from achieving this goal. Objectively speaking, how many banks in the Republic of Moldova can claim and demonstrate that they know their customers extremely well and that they analyze potential transactions starting from the customer and not from the product?

- ensuring a mobile banking in order to satisfy the clients' requirements regarding the accessibility at any time to the banking products and services by using different devices, such as: smart phone, smart watch, mobile wallet, tablet, PC, etc.;

- developing a data analytics strategy designed to help customize the bank's financial products and services, which is to provide solutions tailored to the needs of each client;

- selecting the right technological platforms to ensure that the bank can integrate with its customers in an ecosystem for a mutually beneficial relationship.

Obviously, it is vital for banks to become players open to market realities, able to act proactively on changes in the socio-economic environment through innovation and the adoption of strategies and models that keep pace with customer expectations, demographic realities, opportunities offered by alternative sources, financing of customer activity, the new regulatory framework, the emergence of advanced technologies and new types of competitors, such as FinTechs (technology providers for the financial services industry).

\section{References}

1. Barends, A., (2019). What is customer orientation? Retrieved from https://www.effectory.com/ knowledge/what-is-customer-orientation/

2. Bruhn, M., (2001). Orientarea spre client - Temelia afacerii de succes. Bucureşti: Editura Economică.

3. Eskert, S., (1994), Rentabilitatssteigerung durch Kundenbindung am Beispiel eine Buchclubs. Deutschland: Editura Bamberg, Ge

4. Ettlie, J., Johnson, M., (1994). Product Development Benchmarking Versus Customer Focus in Applications of Quality Function Development. Marketing Letters, Vol. 5, pp. 107-116. https://doi.org/10.1007/BF00994101

5. Fisk, P., (2008). Geniu în marketing. București: Meteor Press.

6. Fornell, C., Riemer, M., Stauss, B., (1992). Verbraucherabteilung in Unternehmen - Ein Kommunikationsorientierter An Satz. Marketing und verbraucherpolitik, Stuttgart: C.E. Poeschel Verlag, p. 473-487.

7. Kotler, P., (2004). Principiile Marketing. Ediția a III-a. Bucureşti: Editura Teora.

8. Kotler, P., (2004). Marketing de la A la Z: 80 de concepte pe care trebuie să le cunoască orice manager. Bucureşti: Editura CODECS.

9. Kohli, A., Jaworski, B., (1990). Market Orientation: The Construct, Research Propositions, and Managerial Implications. Journal of Marketing, Vol. 54, No. 2 (Apr., 1990), pp. 1-18. https://doi.org/10.1177/002224299005400201 
10. Kreutzer, R., Schefer D., Venker K., (1991). Database - Marketing - Erfolgsstrategie für die 90er Jahre. Handbuch Direct Marketing, Editura Dallmer, , Wiesbaden, Germania pp 623-685

11. Mistrean, L., (2021). Behavioural evolution of consumers of banking services in the COVID-19 pandemic situation. The Journal of Corporate Governance, Insurance, and Risk Management (JCGIRM). Volume 8, Series 1, p.p. 84-100.

12. National Bank of Moldova, (2021). Statistical databank. Retrieved from https://www.bnm.md/

13. Zaltman, G., (2003). Cum gândesc consumatorii: aspecte esențiale pentru studiile de piață. Iași: Polirom.

14. Лосева, Н., Козлов, А., (2015). Клиентоориентированность в стратегии развития банковских услуг. Retrieved from https://wiseeconomist.ru/poleznoe/96672-klientoorientirovannost-strategiirazvitiya-bankovskix-uslug 